\title{
NEOCORPORATIVISME A L'ESTAT ESPANYOL POSTFRANQUISTA (1977-1983)
}

\author{
Jordi Roca Jusmet
}

\section{INTRODUCCIO: \\ EL DEBAT SOBRE EL NEOCORPORATIVISME}

Des de la meitat dels anys setanta, s'ha encetat un debat internacional cada cop més ampli sobre la possibilitat d'aplicar el terme corporativisme per a entendre determinades evolucions d'alguns països capitalistes amb règim democràtico-parlamentari. Malgrat que diferents autors han utilitzat el concepte (en general, anb adjectius tals com «nou», «liberal», «negociat» o «social» contraposats a «vell», «autoritari» o «estatal») amb difereats matisos, penso que la majoria d'ells han arribat a un mateix paradigma conceptual de referència. ${ }^{1}$

Aquest paradigma es configura en posar de manifest la importància de dos processos que s'han donat en algunes societats capitalistes i que, malgrat que tenen una dinàmica telativament independent, s'han considerat en general fortament interrelacionats. El primer d'aquests processos és que determinades organitzacions hagin adquirit pràcticament el monopoli de representació dels grups socials més importants (el cas més significatiu és el de determinats sindicats com a representants del conjunt dels treballadors); monopoli reconegut, o fins i tot fomentat, per l'Estat a fi que accep-

1. Algunes de les principals contribucions sobre el tema que es poden consultar són: Schmitter and Lehmbruch (ed.) (1979), Lehmbruch and Schmitter (ed.) (1982), Martinez Alier (1977), Crouch (1979), Panitch (1980, 1981), Salvati i Brosio (1979), Salvati (1982), Offe (1981). 
tin, encara que sigui implícitament, certes testriccions en el seu compottament. El segon és que importants decisions polítiques siguin el resultat de l'acord (amb la intervenció directa de l'Estat o, com a mínim, amb el seu suport) entre els líders d'aquestes organitzacions.

En aquest article discuteixo el paper que les relacions neocorporativistes entre els sindicats, les associacions empresarials i l'Estat han tingut a l'Estat espanyol aquests últims anys. El primer apartat està destinat a analitzar molt breument alguns aspectes de les relacions industrials $i$, en particular, de la qüestió sindical en el període de transició política, ja que aquest és un punt de partida inevitable per a entendre l'evolució d'aquestes relacions als següents anys.

Sense renunciar a donar una perspectiva general sobre les pràctiques neocorporativistes a l'Estat espanyol postfranquista, el meu estudi està, si més no, limitat pel fet que alguns problemes rellevants no han estat tractats més que marginalment. En primer lloc, l'anàlisi de les organitzacions empresarials, tema abordat per Salvador Aguilar en la seva contribució en aquesta mateixa revista, ha estat molt menys considerada que la de les organitzacions de treballadors. En segon lloc, els intents d'acord a nivell sectorial entorn a qüestions tals com la de la reconversió industrial haurien de ser, també, molt més analitzats, ja que en aquest article es dedica especial atenció als acords sobre polítiques de rendes, acords que, malgrat que només són un aspecte parcial del fenomen del neocorporativisme han estat històricament fonamentals per a poder parlar d'aquest fenomen tant en el cas de l'Estat espanyol com en el de la majoria de paisos europeus on el concepte és aplicable. Per últim, sense pretendre fer una lista exhaustiva de les limitacions d'aquest estudi, si bé crec que les relacions capital/ treball han de centrar l'anàlisi actual sobte el tema, el concepte neocorporativisme obre una via per a una aproximació a moltes altres problemàtiques socials.

\section{LA «TRANSICIO POLITICA»I ELS PROBLEMES OBERTS EN EL CAMP DE LES RELACIONS INDUSTRIALS}

La transició política del franquisme a un nou règim s'enfrontava al problema de com reorientar el moviment obrer que, als últims anys, havia mostrat, malgrat la persecució política, la seva potencial conflictivitat. Era necessari fer compatibles la legalitat dels sindicats i l'estabilitat de l'ordre econòmic i social; si bé una situació de llibertat sindical podia tenit un paper estabilitzador evitant la tàpida politització dels conflictes, la possibi- 
litat d'actuar amb menys traves crearia fàcilment una gran conflictivitat tenint en compte que, en gran mesura, el canvi politic era associat popularment a alguna mena de "canvi econòmic», almenys pel que fa a millores socials i condicions de treball. En un context de crisi econòmica, era particularment dificii respondre (sense alterat de forma fonamental la distribució de la renda) a aquestes expectatives, via augments dels salaris reals i de les prestacions socials, encara que, òbviament, la crisi econòmica tenia també com a efecte debilitar, des del punt de vista de relació oferta/demanda, la posició reivindicativa dels treballadors. El problema, a més, no es reduĩa a l'evolució dels salaris sinó que es tractava d'evitar, en un sentit més ampli, la conflictivitat política i social.

Es difícil avaluar la probabilitat que la tadicalització del moviment obrer hagués continuat en la línia dels anys de la transició, un cop passat el particular moment del canvi en el règim polític; és també qüestionable, a un nivell més general, si l'activitat sindical per ella mateixa té possibilitats de transcendir el seu caràcter defensiu o el seu paper bàsicament econòmicoreivindicatiu $i$ obrir perspectives reals de canvi social, encara que això sembla una qüestió que depèn de la situació històrica, de la qual el caràcter del sindicat no és només efecte sinó també agent actiu, i encara que hi ha exemples històrics (con a l'Estat espanyol al 1936) de transformacions de les relacions de producció encapçalades pels sindicats. El que és indiscutible, però, és que la institucionalització del conflicte va esdevenir, al període 1975-1977, una necessitat crucial i que aquesta institucionalització no era un objectiu fàcil d'assolir.

En aquest context va insistir-se, tant pet part dels medis empresarials com per part de molts economistes, sobre la necessitat que els treballadors adoptessin un comportament gue no agreugés la situació de crisi econòmica. L'objectiu de vèncer la resistència obrera a partir de les consequiències de la crisi comportava no només assenyalar els problemes derivats d'aquesta resistència, sinó també sobrevalorar el possible efecte que sobre l'activitat econòmica tindria la seva solució $i$, en conseqüència, defensar una anàlisi esbiaixada de les causes de la crisi que culpabilitzés el moviment obrer.

El punt de partida per a configurar un nou esquema de relacions industrials era el d'un moviment obter caracteritzat per dues components principals: d'una banda, un alt grau de mobilització basat, en gran part, en la pràctica de la negociació i l'acció «directes» (per caracteritzar amb un adjectiu l'absència d'intermediaris permanents $o$, almenys, l'existència d'un gran control efectiu d'aquests intermediaris per part dels treballadors); d'altra banda, una identificació general amb una organització unitària, les $\mathrm{CCOO}$, que inicialment representava aquesta orientació d'acció directa i que pro. gressivament havia estat controlada pel $\mathrm{PCE}$, que va utilitzar aquest control 
per portar a terme una política d'ocupació dels llocs electius en els sindicats oficials del franquisme.

El PCE va impulsar la creació d'una organització sindical única basantse en el prestigi i la tradició de les $\mathrm{CCOO}$ i utilitzant la seva posició en l'estructura sindical franquista. Aquesta organització no era presentada com un sindicat clàssic d'afiliació individual voluntària sinó com la representació organitzada del conjunt del moviment obrer. Segons la resolució del maig de 1976 del Secretariat de la Coordinadora General de CCOO, hi hauria d'haver un congrés sindical constituent en què participarien representants d'assemblees de făbrica obertes a tots els treballadors: «Partim del dret que assisteix els treballadors per decidir lliurement la seva afiliació. Creiem que a les assemblees s'hauria d'abordar obertament aquesta qüestió i discutir-la amb plena llibertat. Si la decisió fos aclaparadorament majoritària, podria considerar-se la conveniència de l'afiliació de tots els treba1ladors. Malgrat això, els que decidissin excloure's tindrien dret a fer-ho. En qualsevol cas, tant per l'acció sindical en tots els sentits, com per l'elecció de representants a tots els nivells no es farà cap diferenciació o discriminació pel fet d'estar o no afliat.» ${ }^{2}$ Els ditigents comunistes van afirmar que, en un context democràtic estaven disposats a conduir les $\mathrm{CCOO}$ en una via no d'oberta confrontació sinó de negociació i pacte. Era precisament aquesta promesa la que oferien als empresaris a canvi d'un pacte polític antifranquista. ${ }^{3}$

Malgrat que penso que els dirigents comunistes eren sincers en oferit el seu partit com a pilar fonamental d'una nova relació treballadors-empresaris de caràcter corporativista en què l'única organització obrera seria legitimada com Ia indiscutible representant de tots els treballadors i acceptaria iniciar una política de negociació de la crisi econòmica, el projecte estava condemnat al fracàs per diverses raons.

En primer lloc, la tradició radical de CCOO tenia molt poc a veure amb la tecent història d'aquells sindicats eutopeus que, sota orientació socialdemòcrata, havien consolidat una pràctica de pactes socials. Com a segona raó, la legitimació del projecte precisava un procés d'assemblees obertes massives que fàcilment podien conduit a una dinàmica de difícil control; molts militants obrers donaven suport a la proposta de CCOO com a moviment «sòcio-polític» (caracterització que era utilitzada en contraposició a sindicat d'afiliació), precisament, com una opció organitzativa per crear un sindicalisme alternatiu al model europeu burocratitzat. En el tebuig que

2. «Gaceta de Derecho Social», 61, juny 1976, Madrid.

3. Vegeu, per exemple, S. Carrillo (1975). 
CCOO fos l'embrió d'un sindicat «normal» convergien, per tant, ambicions molt diferents (en alguns casos, fins $\mathrm{i}$ tot, oposades).

En tercet lloc, no podia, òbviament, esperar-se molta credibilitat respecte a les promeses comunistes per part de les forces empresarials i dels polítics procedents del franquisme. Per últim, el projecte infravalorava les possibilitats de ressorgiment, en la nova situació política, dels sindicats que, encasa que havien estat quasi al marge del procés de recomposició del raoviment obrer des dels anys seixanta, tenien una forta tradició històrica: la CNT i, especialment, la UGT. Aquestes otganitzacions, a més de les seves dissensions ideològiques, evidentment no estaven disposades a integrar-se en una estructura que implicava pràcticament la seva desaparició $\mathrm{i}$ en la qual, a més, el PCE tenia, almenys inicialment, garantida la seva hegemonia.

En els mesos següents a la mort de Franco va haver-hi un intens debat sobre la futura estructura sindical en termes d'unitat o diversitat (piantejat per UGT i CNT com a unitat enfront de llibertat sindical i per CCOO com a unitat sindical enfront de divisió obrera). La postura governamental va ser clara: mentre que la UGT va gaudir d'una tolerància extralegal que li va permetre celebrar públicament una Conferència a l'abril de 1976 (quan Arias Navarro encara era president del Govern), CCOO hauria de realitzar en la clandestinitat el seu Congrés de juliol de 1976; és en aquest congrés que $\mathrm{CCOO}$ va decidir convertir-se en un sindicat clàssic de lliure afiliació, reconeixent la no-viabilitat del seu projecte (la qual cosa li va suposar l'escissió dels militants maoistes de l'ORT' i del PTE, que van veure en aquesta renúncia una claudicació i que van passar a construir els seus propis sindicats que van anomenar «unitaris» [!]).

\section{EL PACTE DE LA MONCLOA}

Malgrat que la gravetat dels problemes econòmics era reconeguda per tots, la tesposta a aquests problemes era retardada per la particular situació política i no va ser fins després de les primeres eleccions generals (juny 1977) que el tema econòmic va ser enfrontat com a primera prioritat.

El Pacte de la Moncloa d'octubre del 1977 va ser presentat com un acord global en el qual es prometien una sèrie de reformes econòmiques $i$ polítiques com a contrapartida a un conjunt de mesures econòmiques estabilitzadores; l'acord va ser signat pel president de Govern i els líders dels principals partits parlamentaris (UCD, PSOE, PCE, AP, CDC, PNB) en una reunió extraparlamentària $i$ posteriorment aprovat, amb molt poc de- 
bat, a les dues cambres legislatives. Les «contrapartides» que feien digetible l'acord eren una barteja de teformes i compromisos programàtics que, fins i tot, anticipaven qüestions constitucionals i que, en general, es caracteritzaven per la seva poca concreció.

La principal de les mesures econòmiques, apareguda com a decret-llei el 25 de desembre de 1977, era l'establiment que els increments salarials, al 1978, no haurien de superar el 20 per cent (l'augment de la Massa Salarial Bruta, computant els augments per antiguitat $i$ ascensos, podia arribar al 22 per cent), que era la inflació esperada per a aquest any; la norma tenia un caràcter vinculant per al sector públic i de recomanació per al sector privat, si bé el seu incompliment suposaria a les empreses la pèrdua d'ajuts fiscals i crediticis i capacitava (si la norma era superada per pressió sindical) per acomiadar fins el 5 per cent dels treballadors ocupats; d'altra banda, les empreses individuals podien desvincular-se del conveni de sector si les condicions pactades els suposaven superat el màxim establert. La recomanació pel que fa a la distribució de l'increment salarial era que un 50 per cent, com a mínim, fos de caràcter líneal.

L'establiment d'un criteri salarial de referència en funció de la taxa d'inflació esperada (amb una clàusula de salvaguarda segons la inflació real després de mig any) suposava un canvi important respecte a la pràctica anterior de tenir en compte, per pactar nous salaris, la inflació de l'any anterior. La importància d'aquest canvi no és tant la pèrdua de poder adquisitiu, que, en una situació de desacceleració de la inflació, comporta passar d'un criterí a un altre, sinó el fet que el nou sistema permetia plantejar la política salarial directament com a part d'una més àmplia política antiinflacionista, ja que, òbviament, Ia taxa d'inflació esperada a la qual s'ajusten els salaris depèn d'aquesta última. A més, es van pactar d'altres mesures econòmiques estabilitzadores tals com la restricció de l'augment de l'oferta monetària i del dèficit públic i s'acordà la possibilitat molt res. tringida de contractes temporals.

El document d'aquest pacte justifica la seva necessitat no només amb arguments macroeconòmics concretats en el restabliment dels equilibris bàsics (nivell de preus, caiguda de la inversió $\mathrm{i}$ consegüent atur, balança de pagaments) sinó també per la necessitat de crear «un clima de cooperació responsable que contribueixi a la consolidació de la democràcia»; l'argument que presenta la inestabilitat econòmica com un perill irnmediat pel sistema polític democràtic és una característica pròpia del neocorporativisme a l'Estat espanyol i no només d'aquest primer pacte social signat en una situació en la qual la nova constitució estava encara pendent d'elaboració.

Els líders dels dos grans sindicats, UGT i CCOO, no van signar for- 
malment l'acord (com tampoc no ho va fer cap representant dels empresaris), però, de fet, van donar-li suport clarament, com ho confirma el fet que els seus dos màxims dirigents (Redondo i Camacho) votaren al Parlament la declaració de suport al Pacte. La diferència tàctica va ser que mentre la UGT va mantenir públicament una certa distància inicial, CCOO va endegar una àmplia campanya per al seu compliment; els sindicats més petits lligats a partits extraparlamentaris (els «unitaris» SU i CSUT), aixi com alguns corrents dels grans sindicats, es van oposar, igual que la CNT, al Pacte.

\section{ALTRES ACORDS NEOCORPORATIVISTES (1980/1983)}

Malgrat les intencions declarades per les direccions de CCOO i UGT, no es va arribar a cap acord central amb eis empresaris per a afrontar la negociació collectiva de l'any 1979; va ser establert, en canvi, un DectetLhei que fixava una banda salarial amb l'11 per cent i el 14 per cent com a límits (quan la inflació prevista era d'un 13 per cent) i tecomanava, com també ho van fer les posteriors normes pactades, que els augments fossin, exceptuant casos excepcionals, de caràcter proporcional.

L'acord de referència per als anys 1980/1981, l'Acord Marc Interconfederal (AMI), va ser signat únicament per l'organització empresarial, CEOE, i la UGT (amb la postetior adhesió de Unión Sindical Obreta, USO), excloent les $\mathrm{CCOO}$, i va fxar un criteri salarial similar establint bandes salarials entorn a la inflació prevista: una banda del 13-16 per cent per al 1980, i de l'11-15 per cent per al 1981 que seria revisada sí l'augment. dels preus a la primera meitat de l'any superés el 6,75 per cent o el 6,6 per cent en cada un dels casos. L'exclusió de CCOO va ser conseqüència d'oposades posicions tàctiques dels dos principals sindicats, en la seva competència, i d'una situació d'incertesa política (amb els, relativament, dèbils governs de la UCD i la perspectiva de possibles eleccions generals); causes a les quals hauria d'afegir-se el desig de la CEOE d'afavorir la UGT en contra de $\mathrm{CCOO}$ i d'avivar els enfrontaments sindicals. Les diferències entre CCOO i UGT es van concentrar principalment entorn al redactat de la futura llei bàsica de relacions laborals (Estatut dels Treballadors), que va ser aprovada al Parlament després de ser pactada entre la UCD i el PSOE (amb el clima favorable creat per l'acord UGT-CEOE) amb l'oposició del $\mathrm{PCE}^{4}$

4. Sobre les diferentes posicions de CCOO i UGT durant aquest període, vegeu: Fina y Hawkesworth (1982). 
El juny de 1981 va ser signat l'Acord Nacional d'Ocupació (ANE) amb I'estímul donat per l'intent de cop d'Estat del 23 de febrer, com evidencien les declaracions del moment $\mathrm{i}$ el fet que, en contrast amb d'altres ocasions, s'arribés a l'acord sis mesos abans que comencés el periode de negociació collectiva (1982) pel qual s'establia una norma salarial de teferència. L'acord va ser signat per UGT i CCOO, d'una banda, i per la CEOE d'una altra; el Govern va participar directament en la negociació de l'acord i també el va signar. Els partits, en canvi, no van participar formalment en un moment en què, en comparació al de la signatura del Pacte de la Moncloa, tant les organitzacions empresarials com les obreres s'havien consolidat.

Aquí, es pot plantejar una important qüestió en relació a la teoria neocorporativista. En una situació en la qual les organitzacions socials siguin independents, sembla clara la importància de situar quin és el pes relatiu dels dos sistemes de decisió, el dels partits (amb o sense consens) i el de l'acord entre els grups organitzats; en el cas que estem analitzant, on hi ha una clara subordinació dels sindicats UGT i CCOO als partits polítics PSOE i PCE respectivament, si bé la CEOE es pot considerar una organització amb considerable independència respecte a qualsevol partit polític, es podria pensar que és bastant indiferent qui decideixi, ja que, en qualsevol cas, el nucli de decisió residiria sempre en la mateixa élite política i la divisió formal de papers en cada moment marcaria una diferència purament d'imatge. Respecte a aquesta anàlisí penso que, d'una banda, no haurien d'infravalorar-se les implicacions ideològiques, que, com a particular forma de legitimació, comporta la pràctica habitual d'acords en els que directament participen representants de grups organitzats, si bé, d'altra banda, és cert que, en segonss quines circumstàncies, el fet que hi hagi acord per consens entre els partits o entre els grups (dependents d'ells) no és la qüestió fonamental i no pot ser indicadora per ella mateixa del caràcter més o menys corporativista de l'acord.

És en aquest últim sentit, que penso que el Pacte de la Moncloa ha de ser considerat, per la seva particular significació històrica, com un acord no només neocorporativista sinó que suposa una inflexió de les relacions industrials en un sentit neocorporativista; el fet que participessin només Govern i partits polítics ha de veure's precisament com a manifestació de la dificultat que aquest canvi comportava als sindicats, caracteritzats anteriorment per la negativa a qualsevol pacte social, i també del particular moment que travessava l'associacionisme dels empresaris, els quals estaven en procés de formació d'una organització única (la $\mathrm{CEOE}$ ).

Tornant a l'ANE, una de les seves particularitats és que és presen. tat com un acord sobre ocupació i no només sobre salaris o, més exactament, 
com un acotd en què la restricció salarial setia per ella mateixa, via el seu suposat efecte macroeconòmic sobre la resta de variables, una política d'ocupació. Existia també un compromís governamental de seguir una política econòmica que conduís al manteniment de la població assalariada ocupada al final de 1982 en relació a l'ocupada al moment de la signatura (juny 1981); però, malgtat la precisió de l'objectiu a assolir, a l'acord no es van concretar quines serien les mesures de política econòmica que el possibilitarien: no es va, per exemple, quantificar sectorialment els volums d'inversió pública ni assenyalar quines mesures d'incentivació a la inversió privada es prendrien per part de l'Estat ni es van fer previsions sobre ocupació a nivell sectorial. La banda salarial pactada va ser del 9.11 per cent, la qual cosa suposà per primer cop, una acceptació sindical clara d'una reducció del poder adquisitiu dels salaris, ja que la inflació prevista exa del 12 per cent, superior al límit màxim de la banda.

Durant 1982, va haver-hi fortes discussions sobre la interpretació de l'acord i l'avaluació dels seus tesultats: la comissió de seguiment i de control que, amb caràcter també tripartit, havia estat acordada, va ser un òrgan de continu enfrontament més que de consolidació del consens. L'any va estar caracteritzat també pel debat sobre la forma que els futurs acords haurien de tenir: CCOO mantenia, com havia estat la seva postura des del Pacte de la Moncloa, la necessitat d'acords tripartits incloent el Govern i tractant no només de política de rendes sinó de política econòmica en termes més globals i de prestacions socials; la UGT i la CEOE, en aquests moments, es van decantar més aviat per acords bipartits entre la CEOE i els dos principals sindicats.

Després de les eleccions d'octubre de 1982 amb la victòria del PSOE, el tema de la «concertació» tornà a ser centre de discussions $i$, malgrat les enfrontades posicions inicials sobre quina banda satarial calia establir, s'ar: tibà a un acord en el que els sindicats van reduir les seves exigències acceptant uns limits del 9,5.12,5 per cent, quan la inflació prevista era del 12 per cent. Aquest acord, signat al febrer de 1983, va ser anomenat Acord Interconfederal (AI) $\mathrm{i}$, en comparació amb l'ANE, suposà una clata reducció dels temes tractats; el Govern no va participar formalment, però, parallela. ment a les trobades públiques (i també secretes) entre empresaris i sindicalistes, va haver-hi reunions entre el Govern i els representants de cadascuna de les parts, reunions que potser van ser decisives per a evitar una tuptura. Fins $i$ tot, un important punt del programa electoral del PSOE (eí de la limitació de la jornada laboral a un màxim de 40 hores setmanals) va set transferit de l'esfera parlamentària a la taula de negociacions per a la seva concreció: l'argument de la CEOE era que el Govern no 
«Papers»: Revista de Sociologia

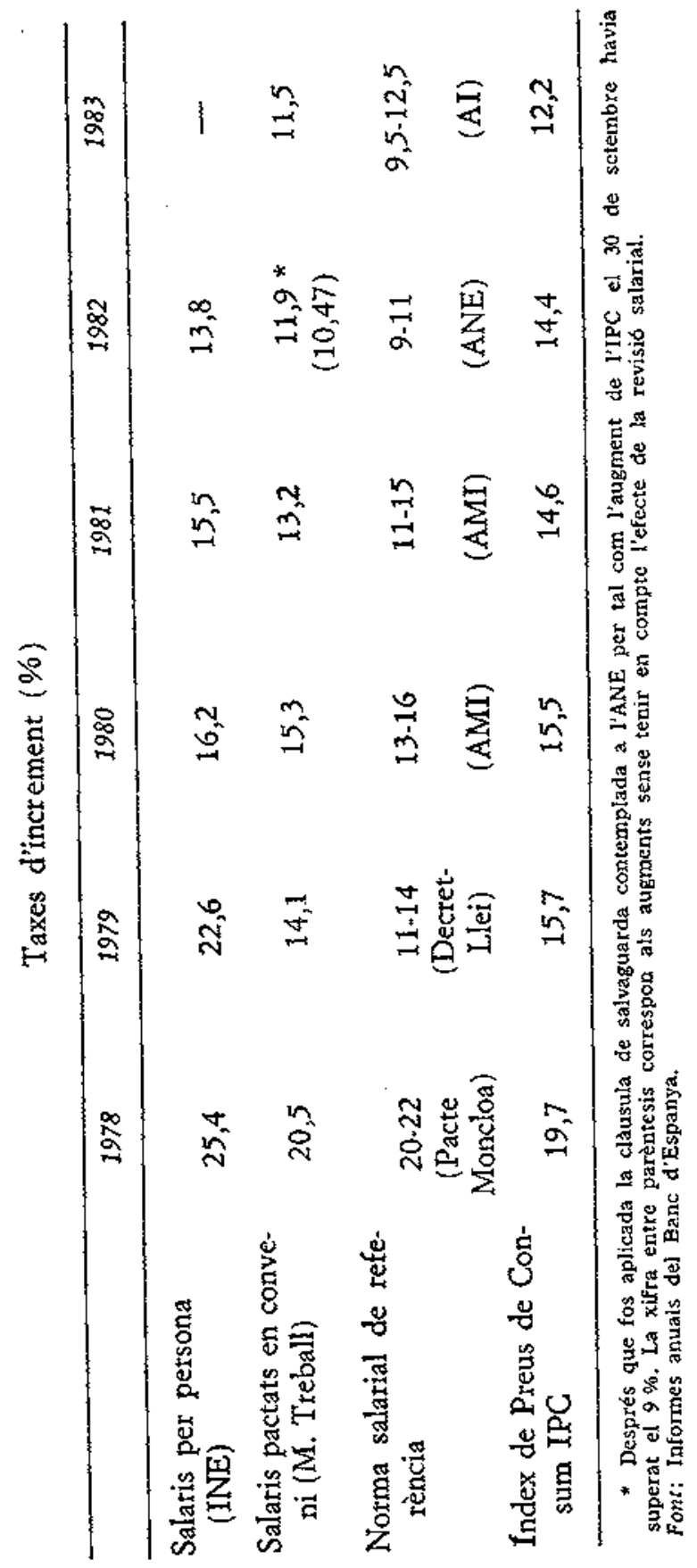


havia de fer un doble joc, acordant d'una banda una limitació dels salaris teals (a través de la UGT) i aprovant al Parlament, d'altra banda, una llei que augmentaria els costos del treball.

\section{EFECTES ECONOMICS DELS PACTES SOCIALS}

\section{SOBRE ELS SALARIS}

\subsection{El grau de compliment de les normes centrals}

$\mathrm{Si}$ observem els increments mitjans de les renunetacions salarials, sembla que, en general, hi ha hagut un grau molt alt de seguiment de les normes pactades als diferents acords neocorporativistes. Aquesta afirmació, però, ha de fer-se amb tota la cautela que la deficiència de les estadístiques salarials imposa $i$ amb la consciència que una anàlisi a fons de la quiestio implicaria treballar amb la informació concreta dels diferents convenis collectius més que no pas amb la variable salarial agregada com a mitjana.

Les dades dels dos indicadors disponibles sobre salaris agregats referents. als últims anys són els que mostra el quadre de la pàgina anterior.

Malgtat la insuficiència de la informació estadística, penso que es pot concloure, com ha fet A. Meixide (1982), que la fixació de límits salarials to ha tingut com a única conseqüència la desacceleració del procés inflacionista sinó que, a més d'afectar les variables nominals (monetàries), ha tingut també efectes reais sobre la distribució de l'ingrés, com es reflecteix en el canvi de tendència palesat en les estadistiques de distribució funcional del Producte Interior Brut a partir de 1978 (vegeu el quadre de la pàgina 96).

Encara que hom centri la seva atenció únicament en el sector industrial i tingui en compte la justificada distinció que el Banc d'Espanya fa entre la variable rellevant per a la presa de decisions empresarials en el sector, que és el cost unitari del treball (incloent les cotitzacions socials) deflactat per l'índex de preus industrials, i la que és rellevant per a 'assalariat, el salari net no només de cotitzacions socials sinó també d'impostos, deflactat per l'index de preus de consum, s'imposa la conclusió que els costos salariais unitaris estan disminuint. Així, segons les pròpies dades del Banc d'Espanya, el cost salarial per persona a la indústria deflactat per l'índex de preus d'aquest sector estaria, des de l'any 1980, creixent per sota de la productivitat observada. ${ }^{5}$

5. Segons el Banc d'Espanya, el cost laboral real per unitat de producte «amb productivitat mitja observadas passaria, al sector industrial, d'un valor 100 l'any 1970 
«Papers»: Revista de Sociologia

Distribució funcional del Producte Interior Brut al cost de factors (\%)

\begin{tabular}{llccc}
\hline Any & $\begin{array}{c}\text { Remuneracio } \\
\text { del treball }\end{array}$ & $\begin{array}{c}\text { Sous i salaris nets } \\
\text { (de cotitzacions } \\
\text { socials) }\end{array}$ & $\begin{array}{c}\text { Cotitzacions } \\
\text { socials }\end{array}$ & $\begin{array}{c}\text { Excedent brut } \\
\text { d'explotació }\end{array}$ \\
\hline 1965 & 48,2 & 41,9 & 6,3 & 51,8 \\
1970 & 52,04 & 43,35 & 8,69 & 47,96 \\
1975 & 56,87 & 45,89 & 10,98 & 43,13 \\
1976 & 58,05 & 46,34 & 11,71 & 41,95 \\
1977 & 58,05 & 45,73 & 12,32 & 41,95 \\
1978 & 57,57 & 44,76 & 12,81 & 42,43 \\
1979 & 57,60 & 42,26 & 13,34 & 42,40 \\
1980 & 56,67 & 43,07 & 13,60 & 43,33 \\
1981 & 56,67 & 42,86 & 13,81 & 43,33 \\
1982 & 55,56 & 42,22 & 13,34 & 44,44 \\
\hline
\end{tabular}

Font: Comptabilitat Nacional d'Espanya INE, Madrid, 1982, i Informe anual del Banc d'Espanya, 1982.

\subsection{L'evolució de l'estructura salarial}

Una important diferència entte les reivindicacions salarials pre-Pacte de la Moncloa i les posteriors és que, en general, s'ha passat d'una pràctica sindical de negociació collectiva tendent a reduir les diferències salarials relatives amb augments monetaris iguals en termes absoluts per a totes les categories professionals a una altra en la qual s'accepten augments iguals en termes percentuals (el que suposa un manteniment d'aquestes diferèn(ies).

El punt de transició va ser la signatura del Pacte de la Moncloa, on es recomanava, encara, que almenys la meitat de l'augment salarial es distribuis de forma lineal entre els treballadors. Des d'aquell moment, totes les polítiques de rendes han establert que els augments salarials tinguessin, excepte en casos especials, un catàcter totalment proporcional. Sembla que el pas per a convertir en criteri general el no-qüestionament de l'estructura salarial ha estat una de les preocupacions principals dels empresaris i dels organismes oficials en aquesta etapa de transició.

El concepte de «solidaritat» ha estat emprat per a legitimar les pràcti-

a un valor 133,4 l'any 1982. El punt més alt seria el de l'any 1979 anb un valor de 149,4 a partir del qual s'inicia la disminució (Banc d'Espanya, 1983, p. 144). 
ques neocotporativistes en el sentit que la moderació salarial suposaria un sacrifici per al sector més privilegiat dels treballadors (els ocupats) que repercutiria, sense oferit, però, garanties en aquest sentit, en favor dels més desafortunats (els aturats). ${ }^{6}$ Malgrat això, no hi ha hagut cap utilització del terme solidaritat per a justificar una crida generalitzada per assolir un igualitarisme salarial més gran de manera que el sacrifici repercutís sobretot en les categories assalariades millor remunerades; al contrari, l'evolució és justament la contrària, malgrat la debilitat de qualsevol atgument econònic que expliqui la necessitat d'una escala determinada de salaris.

En el cas espanyol, per tant, hom no podria dir que la política dels grans sindicats persegueix, en expressió de Panitch (1981), el «socialisme en una sola classe». Aquesta encertada expressió està destinada a descriure aquelles situacions en les quals la moderació salatial per a preservar els guanys (no qüestionant-se la distribució bàsica de la renda entre assalariats $i$ empresaris) va acompanyada d'una política salarial igualitarista que intenta legitimar la participació sindical en els pactes socials.

Pel que fa a l'evolució de l'estructura salarial interindustrial en els taltims anys, Meixide (1982) ha comprovat que després de 1979 es produeix un canvi en la tendència de disminució en la dispersió intersectorial dels salaris que s'havia manifestat a partir de 1976, i diu que: «Es lògic suposar que bona part d'aquests canvis estan relacionats amb les modifica. cions sofertes per la política salarial després dels Pactes de la Moncloas (p. 107).

En aquest sentit, pot assenyalat-se:

- Una important diferència respecte al Pacte de la Moncloa és que, en comptes de fixar únicament un límit salarial màxim, tant el Decret-Llei per a 1979 com els successius acords fixen una banda de referència i explici-

6. El debat sobre el neocorporativisme no hauria de deixar de banda Ia discussió sobre les teories mactoecondmiques que hi ha implícites en la suposada zelació inversa entre variacions salariałs $i$ variacions en el nivell d'ocupació via l'efecte de les primeres sobre les decisions individuals d'inversio; en la mesura que una disminucio dels salaris teals no només augrienta els excedents empresarials sinó que també té efectes sobre la demanda intetior, el seu efecte últim sobre el nivell de producció (i, encara més, sobre el nivell d'ocupació) és, en principi, indeterminat.

D'altra banda, hauria de discutir-se tambe el significat i les consequiències del fet que la majoria de forces polítiques i sindicals acceptin que la politica econòmica quantifiqui els seus objectius en termes del comportannent agregat de variables agregades tals com volum d'inversió i de producció. Utilitzar aquest lienguatge i no parlar sobte què produir i en funció de quines prioritats socials té, malgrat la seva aparent neutralitat, fortes implicacions ideotògiques.

A Ia meva tesi de llicenciatura (Roca, 1984) tracto aquestes qüiestions i altres problemes econòmics relacionats amb el tema del neocorporativisne. 
ten que un dels criteris pet a fixar els increments dintre dels límits matcats serà el de l'evolució de la productivitat.

- A l'AMI i als posteriors acords s'estableix un tracte diferenciat per a les empreses afectades per plans de reestructuració industrial segons el qual s'establiran acords especials sobre la qüiestió salarial en aquestes empreses.

- Amb l'AMI s'introdueix una clàusula de desvinculació que diu: «Els percentatges salarials establerts no seran de necessària o obligatòria aplicació per a aquelles empreses que acreditin objectivament $i$ fefaent situa. cions de dèficit o pètdues mantingudes en els exercicis comptables de 1978 i 1979. També es tindran en compte les previsions per a 1980.» D'aquesta forma, un conveni deixa de ser el mínim legal, a aplicar en matèria salarial, per qualsevol empresa afectada per ell. És aquest un cas clar de "fiexibilitat esbiaixada» a favor de les empreses, ja que a més d'admetre la possibilitat d'incompliment dels increments pactats en conveni, els sindicats han renunciat, en general, a la idea de «negociació articulada», que plantejava que els convenis del sector haurien de flxar uns mínims per a totes les empreses i després hauria de discutir-se empresa per empresa la possibilitat de superar aquests límits. Evidentment, els empresaris han estat d'acord a suprimir aquesta «fiexibilitat» cap a dait.

Sense pretendre entrar de fons en un debat general comparatiu dels mercats de treball en el franquisme $i$ en el postfranquisme, vull fer alguns comentaris sobre la tesi que manté que la situació actual d'aquest mercat està caracteritzada per una més gtan rigidesa que la que hi havia durant el franquisme (J. L. Malo de Molina, 1983) i, en particular, sobte l'anàlisi defensada per V. Pérez Díaz (1984) segons la qual la politica de pactes socials hauria tingut uns efectes que haurien legitimat el sistema econòmic acompanyats, però, d'efectes econòmics negatius concretats no només en una suposada redistribució desfavorable als empresaris (!!) sinó també en una creixent rigidesa del mercat de treball. Aquesta anàlisi contrasta amb el fet empíric del que va passar durant els anys de transició política, en un context de negociació collectiva lliure imposada pels treballadors, quan es va produir un fort escurçament de les diferències salarials tant per categories com per sectors, $i$ amb el fet que, com veurem al següent apartat, els pactes socials han ajudat a superar una part de la resistència sindical a acceptar una disminució de les garanties d'estabilitat del lloc de treball.

A més d'aquests fets empírics, s'obren importants problemes teòrics per a la utilització dels conceptes flexibilitat/rigidesa com a mesura general del grau de desviació respecte a un suposat comportament lliure del mercat de treball. Aquests conceptes tendeixen a presentar els des- 
equilibris en el mercat de treball $i$ les variacions salarials no reduibles a explicacions «econòmiques» (en termes d'oferta i demanda) com si fossin un resultat de l'actuació de factors que són considerats externs al propi mercat $\mathrm{i}$ que el distorsionen. Tant l'existència d'un matc institucional que lirniti les possibilitats de comportament dels agents econòmics com, en últim terme (encara que això no s'acostumi a dir explícitament), la mateixa existència de sindicats podrien ser inclosos dintre d'aquests factors. De fet, però, el suposat comportament individual al mercat de treball que, segons aquesta visió, definiria la racionalitat econòmica no és més que la idealització d'una situació extrema de desorganització, de falta de cons. ciència solidària dels treballadors $i$, fins $i$ tot, d'absència d'efectes emulatius derivats de la compatació de salaris; d'altra banda, les polítiques salarials aplicades a cada empresa responen a criteris que no són reduibles (ni ho serien en el cas d'absència de restriccions institucionals) a ajusta. ments a la conjuntura econòmica externa.

\section{SOBRE LA SEgURETAT DEL LLOC DE TREBALL}

Sense entrar en l'anàitsi del conjunt de la legislació sobre condicions de contractació continguda a l'Estatut dels Treballadors, que en general es pot considerat que, respecte a la situació franquista, amplia els casos de possibilitat d'acomiadament justificat (si fem la importantíssima exciusió dels casos deguts a motius político-sindicals) i que abarateix les des. peses que per a l'empresari comporten els diversos tipus d'acomiadament, em limitaré a assenyalar algunes mesures que, en aquest sentit, han estat introduïdes en els pactes socials dels últims anys.

- Al Pacte de la Moncloa s'estableix l'autorització de contractació temporal, amb un termini màxim de dos anys, quan es tracti de nous llocs de treball creats a partir de l'l de novembre de 1977 i quan aquests liocs de treball siguin coberts per joves que treballin per primet cop. En aquests casos, així com en els contractes temporals de persones acollides al subsidi d'atur amb posterioritat a I'l de novembre de 1977, l'Estat satisfarà el 50 per cent de les cotitzacions a la Seguretat Social.

- A l'ANE hi ba un compromís per a desenvolupat legalment la possibilitat, recollida a l'Estatut dels Treballadors, de contractes especials (els contractes a temps parcial, els contractes de formació i de pràctiques i, sobretot, els contractes temporals). L'ANE diu que «el Govern promulgarà, de forma immediata, la corresponent normativa, prèvia consulta a les Organitzacions Sindicals i Empresarials signants d'aquest acord». El 
desenvolupament legal d'aquesta normativa ha estat posteriorment objecte de moltes tensions per la confrontació de criteris pel que fa a quina mena de llocs de treball podien ser coberts amb treballadors temporals $i$ quin percentatge de treballadors sobre el total de la plantilla podia estar afectat per aquesta mena de contractes.

D'altra banda, en aquest acord hi ha un compromís per fomentar l'ocupació de determinats collectius de treballadors (els que no reben cap mena de subsidi d'atur i tenen responsabilitats familiars $i$ els que han esgotat la prestació). Això es concreta en la subvenció estatal (que pot arribar fins a un 90 per cent) de les cotitzacions a la Seguretat Social quan són contractes de persones incloses en aquests collectius, ja siguin (aquests contractes) de caràcter indefinit o de caràcter temporal. S'obre, per tant, la possibilitat, que, de fet, ha estat denunciada com a pràctica freqüent, que els empresaris decideixin substituir, per motius de rendibilitat, treballadors fixos ger treballadors temporals aprofitant els avantatges de les bonificacions, que poden, fins $\mathrm{i}$ tot, supetar els costos d'acomiadament.

\section{SOBRe La iNversió, la inflació I l'ocupació}

Les polítiques de tendes prenen com a variable instrumental els salaris negociats en converi encara que la variable-objectiu sobre la qual es vol incidir són els salaris efectivament percebuts. Aquesta última variable, però, és sempre presentada com a objectiu intermedi per assolit un creixement de la inversió i una desacceleració de la inflació $i$, en últim terme, un increment de l'ocupació, ja que la reanimació de la inversió i la disminució de la inflació són considerades condicions necessàries per a la creació de llocs de treball.

Si més no, gran part de la credibilitat social dels acords ve condicionada per la previsió del seu impacte sobre l'evolució de l'atur. L'únic cas en què es va formular un compromís explícit en aquest sentit va ser a l'ANE; la promesa, petò, no va complir-se, ja que es va produir una disminució de la població assalatiada ocupada.?

Els acords salarials, pet tant, no han frenat la tendència decreixent en el nivell d'ocupació. Igualment, no s'ha evidenciat una correlació posi-

7. El compromis era que la població assalariada ocupada no seria al final de 1982 inferior a la que era al moment de la signatura de l'acord. El fet és que hi va haver una disminució de 81.000 assalariats $\mathrm{i}$ es va passar de 7.719 .000 ocupats (juny 1981) a 7.638.000 (desembte 1982). Font: Enquesta de Població Activa (INE). 
Neocorporativisme a l'Estat espanyol postfranquista (1977-1983)

tiva clata entre les variacions en els excedents empresatials i el comportament de la inversió. ${ }^{8}$

Les xifres següents mostren aquestes tendències:

Evolució de l'ocupació (\%)

\begin{tabular}{lcc} 
Anys & Taxa d'atur * & $\begin{array}{c}\text { Taxa de variació de la població } \\
\text { ocupada }\end{array}$ \\
\hline 1977 & 5,8 & $-0,61$ \\
1978 & 7,7 & $-2,90$ \\
1979 & 9,6 & $-2,15$ \\
1980 & 12,6 & $-4,91$ \\
1981 & 15,4 & $-2,75$ \\
1982 & 17,1 & $-0,59$ \\
1983 & 18,4 & $-0,82$ \\
\hline
\end{tabular}

- Corresponent al guart trimestre de carta any.

* Variació de la població ocupada al final de l'any t respecte a la poblacíó ocupada al final de l'any $t-1$.

Font: Enquesta de Poblacio Activa (INE) i elaboració pròpia.

Evolució de la inversió (taxes de creixement teal)

\begin{tabular}{lcc}
\hline & $\begin{array}{c}\text { Formació bruta de Capital } \\
\text { (Capital fix }+ \text { Variacio } \\
\text { d'existencies) }\end{array}$ & Formació bruta de Capital fix \\
\hline 1977 & $-4,0$ & $-0,2$ \\
1978 & $-6,4$ & $-2,3$ \\
1979 & $-1,1$ & $-4,5$ \\
1980 & $+3,2$ & $+0,3$ \\
1981 & $-5,2$ & $+1,0$ \\
1982 & $-1,8$ & $-1,3$ \\
1983 (prov.) & $-1,1$ & $-1,2$ \\
\hline
\end{tabular}

Font: Informe anual del Banc a'Espanya 1982.

8. Això dóna suport empíric a la crítica a l'argument simplista que considera que més guanys implica necessàriament més inversió, encata que ha de matisar-se que el nivell de l'excedent brut d'explotacio, que és la magnitud que dóna la Comptabi- 
L'únic èxit clar és en la desacceleració del ptocés inflacionari, ja que, si ho mesurem per l'index de preus de consum, els augments del nivell de preus a finals d'un any respecte al funal de l'any anterior han estat cada cop percentualment més petits des de l'any 1977, que representa el moment de més gran inflació.

\section{INCENTIUS I RESTRICCIONS PER A INDUIR A UN COMPORTAMENT CORPORATIVISTA}

Seguint la formulació de R. B. i D. Collier (1979), penso que el con. cepte de corporativisme pot ser desagregat en un doble aspecte d'incentius i de restriccions. La idea és que implícitament hi ha una transacció en la qual es renuncia a determinades actuacions a canvi d'obtenir una sèrie de guanys. Els incentius serien totes aquelfes mesures o actituds (per part de l'Estat o d'una altra organització) que tendeixen a consolidar o a afavorir (respecte a altres organitzacions en competència) una determinada organització; les restriccions serien totes les mesures de control que s'establei. xen sobre l'otganització i els seus líders. Els incentius oferts a una organització per l'Estat (o per les aitres organitzacions o persones) no es redueixen a les normes legals adoptades en aquest sentit sinó també a totes aquelles actituds que, a la pràctica, tendeixin a tecompensat aquesta organització pel fet que segueixi una determinada orientació.

En el cas que estic analitzant, penso que és molt clar com l'estratègia d'UGT i CCOO ha anat acompanyada d'una sèrie de fets significatius que globalment es poden veure com uns fets que tendeixen a consolidar aquestes centrals davant d'altres sindicats i com a representants de tots els treballadors (malgrat que, com veurem, els treballadots afiliars són una gran minoria).

Exemples d'això serien:

litat Nacional, no és igual al nivell de beneficis (ni necessàriament té la mateixa evolució). Garrido, Santomà i Trullén (1983) han fet aquesta advertència i han asse. nyalat que una past creixent dels excedents empresarials ha estat absorbida pels costos fanancers, de forma que l'augment d'aquests seria una de les explicacions que Ia moderació salarial no hagi pottat a una recuperació de la inversió privada. Fins i tot, l'INE (1980) afirmava, ja el 1980, que: «El que sí s'ha aconseguit és una clara recuperació de '’excedent brut d'explotació... No sembla, doncs, que siguin els incre. ments salarials els que, per la seva magnitud, estiguin frenant el rellançament de la inversió (p. 121). 
a) El propòsit explícit mostrat en tots els acords centrals d'ampliat l'extensió geogràfica dels convenis collectius. Això significa una major concentració de poders en la direcció dels sindicats, que fa difícil el control per part de les bases sindicals (i dels treballadors no afiliats), control més difícil com més «lluny» està el lloc de negociació, i que fa també di. fícil que els sindicats petits amb implantació molt localitzada puguin jugat algun paper. Segons l'Estatut dels Treballadors (en vigència des de març de 1980), per participar en la negociació d'un conveni, una central sindical necessita tenir un mínim del 10 per cent dels membres dels comitès d'empresa de les firmes afectades pel conveni (amb l'excepció dels sindicats, tals com ELA/STB, que només actuen a nivell d'una «comunitat autònoma» que poden participar en negociacions d'àmbit estatal si tenen aimenys el 15 per cent de representativitat en la seva àrea d'actuació). Els convenis collectius firmats pet sindicats que totalitzin més del 50 per cent de la representativitat mesurada d'aquesta forma i per associacions empresarials a les quals pertanyin més de la meitat de les empreses afectades adquiritan «eficàcia general», és a dir, que la seva aplicació pot ser requerja per qualsevol de les dues parts a través de la jurisdicció laboraf, no podent-se desvincular unilateralment una de les dues parts. Aquí es pot assenyalar la asimetria en els requeriments legals per participar en la negociació collectiva: mentre les organitzacions empresarials necessiten tenir un 10 per cent d'empreses afiliades, els sindicats necessiten tenit un 10 per cent de representació electoral, que és compatible amb un baix percentatge d'afiliació ( $i$, fins $i$ tot, amb un percentatge de vots sobre el «cens electoral» moit més baix del 10 per cent), cosa que, en la pràctica, dóna un quasi-monopoli de representació a CCOO i UGT sense el requeriment, però, de cap nivell mínim d'afiliació.

b) La possibilitat d'immediat descompte de les quotes dels afiliats per les empreses va ser introduida a l'AMI per a les firmes de més de 250 empleats sempre que el sindicat en qüestió tingués un mínim d'afiliació del 15 per cent de la plantilla. A l'ANE, la mateixa possibilitat va ser introdü̈da, $i$ es va estendre també a totes les empreses públiques a favor dels sindicats que havien firmat l'acord (sense la clàusula del 15 per cent).

c) Els diferents acords han previst la representació formal dels sindicats en diversos organismes públics, encara que, en general, hi ha bagut més aviat poc compliment d'aquests propòsits. En el Pacte de la Moncioa es parlava del propòsit que els sindicats (i les associacions empresarials) participessin, d'acord amb els resultats de les eleccions als comitès d'empresa, en la gestió de la Seguretat Social, així com en la direcció de les empreses estatals $i$ en la Junta Superior de Preus. A l'AMI i a l'ANE s'expressava de nou el desig (a l'ANE amb l'aprovació explícita del Go- 
vern) de tepresentació de sindicats i empresaris en una àmpita varietat d'organismes. ${ }^{9}$ Quins sindicats tindrien dret a participar i a partir de quin criteri de representativitat va ser una qüestió ambigua fins que l'Estatut dels Treballadors va establir clarament un criteri per a considerat una central representativa a nivell institucional (el 10 per cent del total de membres de comitès d'empresa en el conjunt del territori estatal o el 15 per cent en qualsevol «comunitat autònoma» per a centrals que no actuen en tot l'Estat, com a mínims necessaris).

d) Després de la signatura de l'ANE, va ser acordada bilateralment pel Govern i pels sindicats signants una subvenció directa a aquests amb càrrec al pressupost de I'Estat. Aquest acord significava distribuir 800 milions de pessetes anuals (durant 1982, 1983 i 1984) entre els sindicats, d'acord amb els criteris que ptoposessin UGT i CCOO, i no formava part de l'ANE sinó que, de fet, va comptar amb l'oposició de la CEOE. Hi va haver, posteriorment, una gran confusió sobre quins criteris caldria aplicar per a la distribució i sobre el concepte que justificava el subsidi normalment anomenat de «consolidació sindical» però també defensat com una compensació pel retard en la devolució del «patrimoni sindical», potser com una maneza d'evitar l'impacte que sobre l'opinió pública podtia tenir la falta d'independència financera dels sindicats. El conflicte va ser finalment resolt pels tribunals laborals (pel Tribunal Central del Treball) que, atenent un recurs presentat per la $\mathrm{CNT}$, van declarar anticonstitucional el requeriment d'un mínin de representació per a aquesta qüestió i van obligat a un repartiment segons un criteri d'estricta proporcionalitat atenint-se als tesultats de les últimes eleccions als comitès d'empresa sense marginar a cap central per petita que fos; aquesta resolució, si bé va perjudicar CCOO i UGT (més políticament que econòmicament) va, paradoxalment, excloute precisament la CNT que (m'estic referint a la «CNT.Vè Congrés» que és una de les dues centrals que, després de l'escissió de 1979, reivindicà aquest nom històric) és partidària del boicot a les elec. cions per a comitès d'empresa i que, amb el seu recurs, pretenia, més que discutir les normes concretes de distribució, discutir la legitinitat del subsidi, ja que aquest posava en peritl la independència, constitucionalitzada també, dels sindicats respecte a l'Estat. ${ }^{\text {to }}$

9. La UGT (1981), en un libre de comentari sobte ''ANE, enumera 18 instituts administratius afectats per la participacio isstitucional promesa en aquest acord (vegeu quadre XIV a les pàgines 144145 d'aquest llibre).

10. Es important assenyalar la importància que, segons els números presentats al 33è. Congrés de la UGT («El Pais», 23-V-1983), representava la subvenció estatal. L'ingrés esperat el 1983 per aquest concepte (més de 487 milions de pessetes) supe. raria les previsions de recaptacions per quotes sindicals (al voltant de 350 miliors). 
e) Hi ha hagut intents d'aplicat en alguns convenis collectius (encara que com a fet aillat) una mena de «cànon sindical» o "quota de negociació» que haurien de pagar, o bé, els no afiliats, o bé, tots els treballadors. afectats pel conveni i que, en concepte de despeses de representació aniria a benefici dels sindicats que signessin el conveni. L'argument és que, si tots els treballadors tesulten beneficiats de les condicions pactades, no és just que els costos per a possibilitar aquestes condicions recaiguin només en els afiliats o, en termes més familiars a la teoria econòmica, si el resultat de la negociació collectiva és un «bé públic» per a tots els treballadors afectats, és lògic imposar un impost per pagar aquest bé perquè no hi ha incentius per a decidir individualment contribuir als costos. En els casos, però, que aquesta mena d'afiliació obligatòria ha estat impugnada, el Tribunal Central del Treball l'ha declarat anticonstitucional. La CEOE s'ha oposat en tot moment a tal pràctica, mentre que alguns liders d'UGT l'han defensada explícitament $\mathrm{i}$ els de CCOO han tendit a evadir una definició al respecte."

Aquestes últimes dues qüestions mereixen un cornentari. En un context de debilitat organitzativa dels sindicats (que després comentaré), les. qüestions financeres tenen implicacions per a l'estudi del corporativisme. D'una banda hi ha necessitat de sindicats forts, $i$, per tant, amb suficients mitjans econòmics, però, d'altra banda, hi ha un problema de legitimació de formes de financiació alternatives al lliure pagament de quotes. La qüestió és que, si els sindicats són considerats organitzacions independents de l'Estat $i$ de lliure afliació, és difícil justificar que siguin, en part, finançades a través de l'Estat, és a dir, amb els impostos pagats per tots els ciutadans o a través d'una quota més o menys obligatòria, pagada també pels treballadors que decideixin no afiliat-se; aquesta última pràctica si bé és propia del «corporativisme estatal» no ho és d'una societat amb libertat d'organització.

f) La Constitució (article 131) diu que, en cas de fer-se necessària la planiffcació econòmica, hauria de crear-se un Consell Econòmic i Social consuitiu per a aquest objectiu; la concreció pràctica d'aquest organisme, però, no ha estat efectuada ni pels governs d'UCD, malgrat haver-hi una

11. Per part de $\mathrm{CCOO}$, si bé va signar algun conveni en el qual s'imposava et càzon i no va haver cap reacció pública per part de la direcció del sindicat (maigrat: la publicitat donada al tema per Ia premsa i molgrat la polèmica suscitada), la posrura s'ha fet més clara en el sentit de rebutjar la possibilitat d'estabilment del cànon. El fet que el govern socialista pteveu, ai seu ptojecte de «llei orgànica de llibertat sindical», la possibilitat del cànon, ha originat l'oposició de la direcció del sindicat. La discussió del projecte socialista sobre libertat sindical és molt important per al nostre tema, però no entra dins el perfode analitzat per aquest article. 
proposictó de llei al respecte, ${ }^{12}$ ni, de moment, per l'actual Govern del PSOE, malgrat que el Consell formava part del seu programa electoral com l'instrument concret per a dur a terme la «planificació concertada». Si bé la política corporativista pot perfectament funcionar via contactes informals, i el que és més important no és que existeixi o no formalment un organisme d'aquesta mena (que si existís podria tenir molts diversos impactes sobre la política efectiva), la seva institucionalització podria suposar, en el cas espanyol, una important pressió per assegurar una continuitat en la pràctica de la concertació i, com veurem, el fet que el Govern socialista hagi renunciat a crear aquest organisme de forma urgent (abans de qualsevol opció planificadora i de política de rendes) és molt signifcatiz.

Tant si és presentat com un organisme únicament per a la planificació o també per a la concettació, el fet és que qualsevol planificació implica òbviament fer previsions sobre les grans magnituds de la Comptabilitat Nacional i, per tant, sobre el ritme de creixement de les remuneracions salarials (com realment ha succeit al programa econòmic elaborat unilateralment pel Govern), de manera que un acord sobre aquestes previsions implica un acord sobre política de tendes. Segons alguns mitjans de comunicació, fa mesos que existeixen avançats esborranys concretant propostes sobre la futura composició del Consell. La composició prevista inclou membres en representació de diversos ministeris, de les comunitats autònomes, de les institucions financeres (Banc d'Espanya, Institut de Ctèdit Oficial, Banca Privada i Caixes d'Estalvis), dels sindicats i organitzacions empresarials, d'organitzacions agràries i collegis professionals, així com representants d'organitzacions socials, tals con les de consumiciors i ecolo gistes, $i$, segons algunes versions, membres escollits directament per les Corts. El Consell, evidentment, no ha rebut, per part dels seus proponents la caracterització de tercera cambra ni d'òrgan corporativista sinó que, al contrari, s'ha negat categòricament que aquests termes poguessin ser apticats en aquest cas.

8) Finalment, vull assenyalar un punt molt menys tangible que és el de l'actitud de l'Estat $i$ de gran part de l'empresariat favotable a donar a la UGT i CCOO una mena de "reconeixement social» com a representants del conjunt de treballadors en una forma que excedeix un criteri estricte d'importància numèrica sigui $\mathrm{ja}$ en termes de delegats obtinguts electoralment o en termes de nombre d'afliats. En aquest sentit, és curiós

12. Presentada el 17 de novembre per part del diputat Ramón Tamames, ex-dirigent del PCE i, en aqtrell moment, membre del Grup Mixt. Sobre aquesta proposta vegeu Tamames $(1981,1982)$. 
observar com, durant els últims anys, les organitzacions empresarials i els representants governamentals han posat molt poc èmfasi sobre l'espectacular pètdua d'afiliació de tots els sindicats $i$, excepte ocasions ailliades, quan la qüestió ha estat alludida ho ha estat més com a causa de preocupació i com a problema a solucionar que com a argument per a qüestionar la seva representativitat.

\section{L'EVOLUCIO DE LA SITUACIO SINDICAL}

\section{Divisió SINDICAL}

La divisió entre els dos principals sindicats és un obstacle per a l'estabilitat de les estructures neocorporativistes. L'absència d'unitat organitzativa no ha estat, a més, substituîda per una efectiva coordinació i unitat d'acció a nivell sectorial i d'empresa. El patró predominant ha estat el d'una forta competència entre les dues centrals sindicals, competència que no ha exclòs, però, una política conjunta dirigida a eliminat els sindicats més petits.

La competència va ser particularment forta en els anys postetiors a l'assoliment de la llibertat de sindicalització, moments en què la UGT necessitava créixer en perjudici de $\mathrm{CCOO}$, $\mathrm{i}$ en què les normes de representació a rivell de centre de treball estaven encara en discussió. Aquesta competència és una de les principals raons per explicar per què el primer pacte corporativista signat per les dues centrals sindicals no va produir-se fins al 1981. Ja que els dos sindicats tenen una força molt similar, almenys si la jutgem segons els resultats de les eleccions per a comitès d'empresa $i$ delegats sindicals, ${ }^{13}$ i ja que cada un dels dos està lligat a un partit polític diferent, la competència continua $\mathrm{i}$ adquireix particular virulència en els moments d'eleccions sindicals, annb baralles sobre els resul-

13. Els resultats d'aquestes eleccions, en nombre de delegats, han estat (en tant per cent):

\begin{tabular}{llll}
\hline & 1978 & 1980 & 1982 \\
\hline CCOO & 34,45 & 30,86 & 33,40 \\
UGT & 21,70 & 29,27 & 36,71 \\
\hline
\end{tabular}

Font: Ministeri de Treball. 
tats de les eleccions i, fins i tot, amb acusacions mútues de frau. El fet que en aquests moments la subordinació política no sigui respecte a dos diferents partits de l'oposició sinó al partit del Govern en un cas, i a un partit de l'oposició en l'altre, reforça, sens dubte, les tensions.

En algunes tegions, particularment a Euskadi, no existeix aquest pràctic duopoli de reptesentació; el principal sindicat, en aquest país, és el nacionalista ELA-STB, que s'ba oposat a tots els acords produits a nivell estatal, encara que, donada la seva vinculació al nacionalisme moderat i no a l'esquerra «abertzale», possiblement deguda al seu marc geogràftc més que a una altra raó. A les Canàries $i$ a Galícia hi ha també importants sindicats nacionals, igual que en el cas del camp andalús, però aquest fet no es produeix a Catalunya. ${ }^{14}$

Un factor que ha d'afegir-se com a oposat a la centralització de les decisions és el de la divisió dintre d'aquests sindicats majoritaris que, encara que no es concreti en escissions formals, pot suposar dificultats per a la implementació dels acords presos per les cúpules sindicals.

\section{El NIVELL DE REPRESENTATIVITAT}

Un aspecte encara més important és l'espectacular pèrdua d'afiliació de tots els sindicats des de l'any 1978. Si bé no hi ha dades fiables, ni tan sols aptoximades, sobre l'afiliació sindical, hi ha acord que es troba molt per sota de la majoria de paisos europeus $i$, més important encara, és el fet que ha disminuät molt des de 1978. J. A. Sagardoy i D. León Blanco (1982) donen una estimació, per a 1978, basada en els pocs estudis sobre la quiestió, segons la qual estarien afiliats una mica menys del 50 per cent de

14. A Euskadi (sense incloure Navarra), les dades electorals són (en tant per cent):

\begin{tabular}{lll}
\hline & 1980 & 1982 \\
\hline ELA/STB & 25,65 & 30,24 \\
UGT & 19,21 & 21,53 \\
CCOD & 17,59 & 17,12 \\
\hline
\end{tabular}

Font: Ministeri de Trebalt.

En el cas de Gatícia, em refereixo a ia Intersindical Nacional de Trebaliadors Gailecs (INTG) -que a les eleccions de 1982 va treure un $18,94 \%$ de delegats a Galícia. En el cas de Canàries, es tracta del Sindicat d'Obrets Canaris (SOC) i, en el cas andalús, del Sindicat d'Obrets del Camp (SOC). 
treballadors assalariats (incloent els aturats), mentre que per al 1980 estimen, mitjançant tan mètode indirecte basat en la participació i els resuitats de les eleccions a comitès d'empresa, un percentatge d'afiliació del 23 per cent com a màxim. La seva conclusió és: «donada la tendència a la baixa observada, no creiem que superi en aquests moments, a finals de 1981, el 20 per cent» (p. 130). ${ }^{15}$ La situació actual real sembla, segons diversos estudiosos del tema, d'una taxa d'afiliació encara bastant inferior a aquest 20 per cent. ${ }^{16}$

Aquesta evolució exigeix una explicació que només en part es pot trobar en la crisi econòmica $i$ els seus efectes de creixement de l'atur $i$ de segmentació del mercat de treball. Un factor a tenir en compte també, és que el fort creixement dels sindicats després de la desaparició del Sindicat Vertical fou degut, en part, a les expectatives creades sobre els possibles guanys en serveis que comportaria la situació d'afiliació a un sindicat 0 , fins i tot, sobre la necessitat d'estar sindicat; I incapacitat general per crear una infrastructura de serveis adequada pot servir per explicar part del posterior reflux de les taxes d'afiliació: sofisticant l'explicació, la teoria de l'elecció social diria que els treballadors s'afilien o no, després d'una implícita avaluació dels costos que aquesta afiliació els reporta en relació als beneficis individuals resultants i que, si la situació és tal que ser membre d'un sindicat no produeix cap guany diferencial significatiu, com en el cas dels sindicats que quasi no tenen capacitat d'oferir serveis i fan servir una forma de negociació collectiva que no discrimina entre affliats i no afiliats, apareix

15. Això, segons elis, implicaria aproximadament 1.800 .000 afiliats distribuitts de la forma segíent:

Comissions Obreres (CCOO)

730.000

Unió General de Trebaltadors (UGT) ........................... 692.000

Unió Sindicał Obrera (USO) .................................. 205.000

Solidaritat de Treballadors Bascos (ELA.STB) .................. 58.000

Intersindical Nacional de Treballadors Gallecs (INTG) ...... 24.000

Altres sindicats ............................................. 91.000

16. Segons Víctor Pézez Díaz (1984): «El sindicat socialista té, com el comunista, una massa d'afiliació molt modesta (entre un $10 \mathrm{j}$ un $15 \%$, tots dos junts, de la pobiació assalariada del país), encara que tingui també una influència més gran en convenis, conflictes i comitès d'empresas (p. 37).

La UGT ( $\mathrm{El}$ País», 23-V-1983, vegeu nota 10) esperava al 1983 uns ingressos en concepte de quotes d'afliats al voltant de 350 milions de pessetes que, sobre la base d'un pagament mensual de 150 pessetes per afiliat, representatia només 195.000 membres si suposéssim (una suposició que evidentment porta a una infravaloració del nombre d'afiliats) que tots els afiliats pagten regularment la seva quota. 
l'efecte free-rider, ja que l'actitud racional és beneficiar-se de l'activitat del sindicat sense incórter en un cost individual. Malgrat que és obvi que un augment en els avantatges individuals tendirà, ceteris paribus, a augmentar les afiliacions $i$ que un augment dels costos (per exemple, un augment de les quotes sindicals) tendirà a disminuir-la, igualment és obvi que el grau d'afiliació depèn també (o, sobretot) d'altres factors no reduibles a una anàlisi cost/benefici individual: $\dot{c}$ com s'explicaria en termes cost-benefici individual que molts treballadors portessin sota el franquisme una activitat sindical quan aquesta no només no reportava guanys individuals sinó que s'estava exposat a la repressíb policial? Si hom no integra diatre del «càlcul» factors tals com la consciència solidària o les idees polítiques no es pot explicar quasi bé res, ferò, si són integtats, el plantejament de la qüestió com a decisió exclusivament individualista esdevé bastant tautològic (qualsevol decisió seria, per definició, racional).

La meva opinió és que part de l'explicació està directament relacionada amb la política seguida pels sindicats aquests últims anys. Encara que no es pot parlar d'un rebuig majoritari a la política de pactes socials ni, de bon tros, d'un rebuig acompanyat d'una pràctica sindical alternativa; penso que la ruptura que aquests pactes significaven amb la pràctica anterior pot explicar, en part, l'actual desmembrament del moviment obrer. Aquí, però, s'hauria d'explicar per què s'ha produït una pràctica desaparició de les centrals sindicals minoritàries (en especial, la central històrica $\mathrm{CNT}$ ) que es van oposar radicalment a aquests pactes, o per què la pèrdua relativa d'UGT ha estat més petita que la de CCOO malgrat la imatge més moderada d'UGT. En qualsevol cas, un important factor en la pèrdua conjunta d'afiliació crec que és que la negociació sobre salaris i condicions de treball s'ha desplaçat cap a dalt, en contrast amb la forta tradició de negociació a nivell d'empresa als últims anys del franquisme. És així, tant per l'extensió geogràfica dels convenis con pel fet que aquests s'hagin establert durant diversos anys tenint en compte unes prèvies restriccions, amb la qual cosa han perdut contingut.

En estudiar la representativitat, s'ha de parlar no només d'afiliació sinó també del suport donat als sindicats mitiançant les eleccions a nivell d'empresa. En aquest sentit, encara que la taxa de participació, a les empreses on es realitzen, és bastant alta, les eleccions només s'efectuen en empreses que totalitzen menys de la meitat dels treballadors assalariats $i$, el que és més significatiu, el collectiu afectat per les eleccions ha disminuit en les últimes convocatòties. La no-realització d'eleccions en la majoria d'empreses no només ve condicionada per limitacions legals sinó també per la situació sindical. 


\section{INEST ABILITAT I PERSPECTIVES \\ DEL NEOCORPORATIVISME A L'ESTAT ESPANYOL}

La pètdua de força dels sindicats, evidenciada per la progressiva desafiliació, no ha anat acompanyada d'un augment en la credibilitat d'altres alternatives socials. Els acords neocorporativistes, amb la consegient acceptació de determinades limitacions a la negociació collectiva, s'han imposat, més per una actitud conformista en una situació de forta crisi econòmica que com a resultat d'una autèntica impregnació ideològica del discurs dels líders sindicals.

Les qüestions socialment viscudes com els més greus problemes econòmics tals com l'atur (problema agreujat per la baixa taxa de cobertura de les ajudes estatals) i la progressiva segmentació del mercat de treball (que implica que molts treballadors ni tan sols tenen tegulades les seves condicions de treball per contractes legalment establerts), escapen clarament al control, $i$ fins $i$ tot a la influència decisiva, dels sindicats. Quasi bé ningú cteu que realment s'estigui pactant una «sortida a la crisi» o «la distribució equitativa dels seus costos» i tothom sap que els sindicats estan clarament en una posició defensiva; el neocorpotativisme a l'Estat espanyol s'ha reduit pràcticament a la renúncia sindical a contrarestar els punts centrals de l'anàlisi oficial de la crisi econòmica, i a una discussió sobre bandes salarials que afecten a una part cada cop més petita dels treballadors, els legalment ocupats, molts dels quals estan logicament molt més preocupats per la seguretat del seu lloc de treball que per si el seu. salari creixerà un mig per cent més o un mig per cent menys. Els termes en què s'han establert els acords neocorporativistes han estat particularment desfavorables als treballadors, ja que la moderació salarial no ha anat acompanyada de mesures contra l'atur o, almenys, per millorat la situació dels aturats.

Aquests últims anys, tanmateix, la principal tesistència a la persistència i/o l'extensió dels acords neocorporativistes no ha vingut per part dels. treballadors (ocupats o en situació d'atur) sinó que els acords salarials s'han trobat cada cop més amb una actitud general de conformisme o indiferència per part deis que no estan sindicats, mentre que per part dels. afiliats als grans sindicats, malgrat que hi ha hagut importants posicionaments interns contra els pactes socials (o, almenys, contra els termes en què han estat signats), ${ }^{17}$ s'ha donat suport a la continuació de la política

17. Dintre dels grans sindicats, una de Ies més fortes oposicions als pactes ha estat a les $\mathrm{CCOO}$ de Catalunya. Una majorì de membres de comitès d'empresa afliats a CCOO de Catafunya va votar contra la signatura de l'AI de febrez de 1983, encara 
d'acords salarials centrals, encara que aquests acords s'hagin negociat des d'una posició de creixent feblesa.

Sembla que els empresaris han d'estar satisfets amb el desenvolupament de les relacions industrials d'aquests últims anys, i molts d'ells segurament s'han sorptès per l'actitud de moderació adoptada (sense perdre el seu lideratge) pels liders sindicals quan, en canvi, en els moments posteriors a la mort de Franco era clar el perill d'un creixent $i$ incontrolable «conflicte social». Malgrat això, mentre els empresaris, en contrast amb els sindicats, han consolidat una organització unitària que agrupa tant la gran com la petita empresa, hi ha la possibilitat que s'adoptin actituds que tendeixin cada cop menys a la concertació amb els sindicats. En aquest sentit, no només es tracta que persistirà l'opció clara de la CEOE contra les mesures destinades més directament a enfortir els sindicats (tals com els subsidis estatals o l'establiment del ja comentat «cànon sindical») i contra la institucionalització dels acords amb els sindicats, ${ }^{18}$ sinó també que probablement s'adoptaran actituds cada cop menys flexibles respecte a la política salarial. La posició dominant de l'ANE va ser la de continuar cercant pactes amb la UGT i CCOO en què no participés formalment el Govern ni es tractés de qüestions generals de política econòmica si no estaven orientats únicament a assegurar la moderació salarial; tanmateix, la qüestió important ara és que la via dels pactes (quan hi ha més de dos milions d'aturats i uns sindicats cada cop més febles) no és ja percebuda com a imprescindible per arribar a aquesta moderació i pot, fins i tot, pensar-se que amb una negociació collectiva lliure (i molt més amb una negociació condicionada per una recomanació governamental) es podria arribar a similars o més favorables resultats per als empresaris, encara que aquesta alternativa comporta més costos en termes de conflictivitat. Si és veritat que la política dels sindicats ha estat un dels factors que explica la pèrdua de capacitat de mobilització dels treballadors, podríem dir que les pràctiques neocorporativistes en el postfran-

que la seva direcció va decidir (per petita majoria) acatar la resolució adoptaca pel Consell Confederal a Madrid.

18. Després de I'ANE, la postura de l'associació empresarial de negativa a qualsevol acord tripartit ha estat una constant. J. M. Cuevas, secretari genexal de la CEOE parlant a l'OIT a Ginebra, el juny de 1982, va dir que I'ANE, en contrast amb l'AMI, havia suposat «una repolitització de les relacions haborals i el desenvolupament d'una certa forma de neocorporativisme» («El País», 12-VI-1982). En un to més agressiu el seu president, Ferrer Salat, ha arribat a dir que qualsevol intervenció del Govern en el diàleg entre empresaris $i$ sindicats useria la reptoducció dels Pactes de la Moncloa o la resurrecció del "Movimiento Nacional" («Diatio de Barceiona», 24-IX-1983). 
quisme han afavorit l'emergència de les condicions per a una estratègia empresatial no-corporativista viable.

Els socialistes, després la seva victòria electoral d'octubre de 1982, malgrat el que podia esperar-se a la vista del seu programa electoral $i$ amb la idea que en general les tendències neocorporativistes han estat fomentades per la socialdemocràcia quan aquesta ha estat al Govern, no han utilitzat el seu control absolut sobre el Parlament i sobre el Govern per pressionar cap a la «concertació» sinó que més aviat l'han utilitzat per adoptar una actitud molt dirigista reclamant per al Govern la capa. citat d'inciativa i de decisió enfront dels diversos grups.

És molt clar que el Govern socialista podia haver forçat que sindicats i associacions empresarials collaboressin a elaborar la seva política econòmica i social considerada globalment: podia haver intentat aquesta direcció legislant d'immediat sobre el Consell Econòmic i Social perquè es convertís en el centre de discussió del pla econòmic anunciat pel Govern i tractés, amb una perspectiva de conjunt, els temes de la teconversió industrial, els Pressupostos Generals de l'Estat per a 1984 i la política de rendes per a aquest mateix any (o per a un període més llarg). CCOO, des del Pacte de la Moncloa, planteja una proposta «tripartida» d'aquesta mena; UGT, en el seu últim congrés (maig 1983), va teoritzar l'acceptació d'una disminució del poder adquisitiu del salari monetari individual (de fet ja acceptada a la pràctica a l'ANE) introduint el concepte de «manteniment del salari social», que inclouria no només el salari monetari tebut individualment sinó també les despeses públiques en matèria d'educació, salut, subsidi d'atur..., així com les fluctuacions en el nivell d'ocupació: òbviament, la discussió conjunta dels Pressupostos de l'Estat, el pla econòmic i la política de rendes obria pas a les negociacions en aquest sentit; igualment, la discussió (quantificant els objectius) de la política d'inversions públiques $i$ de les mesures per a fomentar la inversió privada podria haver fet més presentable la reconversió industrial, que, almenys a curt termini, comporta una important pèrdua de llocs de treball.

El Govern ha renunciat clarament a aquesta alternativa i va presentar un pla econòmic per al periode 1984/1986 (que ha anomenat, aquest cop, «programa econòmic») i uns Pressupostos per a 1984 elaborats unilateralment pel Govern sense intentar formar abans el Consell Econòmic i Social, ni tan sols una més informal taula de negociació global, i va crear separades «taules de concertació» per discutir la reconversió industrial i per discutir qüestions relacionades amb l'ocupació i amb les modificacions de l'Estatut dels Treballadors, però amb una decisió clara d'imposar per dectet (amb o sense acord) la reconversió industrial, mentre que el marge de discussió sobre qüestions tals com el grau de cobertura del subsidi 
d'atur estava estretament limitat pel condicionament dels Pressupostos ja elaborats. Pel que fa a salaris, la discussió sindicats-empresaris ha estat centrada entom a les xiftes donades pel Govern, que ha pres la iniciativa incloent al «progtama econòmic», sense consultar aquestes forces, una previsió (i als Pressupostos una nornativa per al personal pagat per l'Es. tat) dels augments salarials per als pròxims tres anys: de 6,5 per cent per al 1984 (amb una inflació prevista del 8 per cent), d'un 0,5 per cent per sota de la inflació prevista per al 1985 i del mateix percentatge que la inflació per al 1986.

La situació de debilitat sindical i el suport més o menys explícit d'un dels dos grans sindicats (que, si bé no pot aplaudir totes les mesures governamentals, està clarament disposat a justificat-les) han possibilitat aquesta actitud del PSOE que, sens dubte, ha tingut por d'intentar una política neocorpotativista que comportés concessions (per mínimes que fossin) tespecte a les exigències sindicals, ja que haturia pogut suposar, de fet, una polarització política deguda a l'oposició empresarial; zar la seva majoria absoluta no per portar una política «pro-obrera» en contra de les tesistencies de la dreta sinó per portar una política que s'ha guanyat la simpatia de molts empresaris, si bé la crítica empresarial al Govern ha continuat molt forta en aspectes com el de la seva política financera i de despesa pública.

El cost de la política socialista ha estat frustrar les esperances de la majoria del seu electorat a mesura, sobretot, que es dissipa cada dia més la confiança en la promesa electoral de crear 800.000 nous Ilocs de treball nets durant aquesta legislatura i enfrontar-se als sectors de treballadors més directament afectats per la reconversió industrial, amb les dificultats

19. L'oposició empresarial potser hauria portat a la utilització del terme neocorporativisme per atacar la politica socialista, com ja va fer Ferrer Salat en un article aparegut després de les eleccions: «La CEOE va expressar en el seu moment la seva gran preocupació pels efectes d'una sindicalització global de l'economia i de l'activitat espanyola, ¿ aquesta opinió ha de reiterat-se de nou amb el més gran ènfasi. No es tracta d'una opinió aillada, ja que, des de la doctrina, laboralistes prestigiosos destaquen els riscos d'un burocratisme neocorporativista i d'un pansindicalisme que artibi a desvirtuar el funcionament dels mecanismes ordinaris de les societats democràtiques» (Açualidad Económica), núm. 1.291, febter 1983, p. 131). E1 mateix Ferrer Salat havia arribat a afrmar a la campanya electoral, que el PSOE «pretén sindicalizzar la vida del pais, portant-nos en definitiva a la tornada del Sindicat Vertical» i que, amb la coparticipació, «no es tracta que els treballadors participin a l'empresa sinó que hi participin els sindicats, això és, eís que reptesenten el $10 \%$ dels treballadors» ( «El País», 22-X-1982). Aquesta és una de les escasses referències públiques al grau d'afiliació ais sindicats que, per part dels dirigents empresatials, s'han fet per a qüestionar que aquests puguin parlar en nom de tots els treballadors (referències que és previsible siguin cada cop més freqüents). 
que això comporta a la UGT per justificar la política governamental sense perdre la seva credibilitat com a sindicat.

El fracàs de les negociacions per establir una banda salarial de referència per a l'any 1984 (tema que no pertany al període analitzat en aquest estudi) crec que confirma les meves conclusions en la mesura que demostra que la CEOE ha pogut mostrar-se inflexible en les seves posicions (una banda centrada entorn a la recomanació governamental del 6,5 per cent i que tingués com a límit superior un increment del 7,5 per cent, inferior al 8 per cent d'inflació prevista) amb el suport implícit del Govern, convertit en explicit quan, desptés de la ruptura de negociacions, representants governamentals declaraven que era millor aquest resultat que no una superació de la norma establerta. Aquesta actitud contrasta amb la que va prendre el Govern en el moment de les negociacions de l'acord salarial per al 1983, en què va intentar conciliar les postures enfrontades.

Potser seria perillós, però, treure la conclusió que s'ha obert definitivament una etapa en la qual el neocorporativisme jugarà un paper cada cop menys important. El fet conjuntural que un any determinat Govern i associacions empresarials renunciïn a establit una política de rendes no ha de sobrevalorar-se $i$, fins $i$ tot, pot considerar-se com una mena d'assaig per veure quin és el resultat de la negociació collectiva lliure quanat a increments salarials i quant a conflictivitat. No sembla que el Govern tingui una postura encara definitiva al respecte pel que fa als anys pròxims. De totes formes, no sembla que un govern socialista pugui arriscar-se a explotar al màxim una actitud antisindical posant en perill el suport d'una part de la seva base social; la «llei orgànica de libertat sindical» preveu significativament, com ja he assenyalat, no només garanties pel que fa a continuar considerant els sindicats majoritaris com a forces socials representatives sinó que legalitza la possibilitat d'establir el comentat «cànon sindical».

$\mathrm{Si}$ bé les dues variables que caracteritzen el fenomen del corporativisme -concertació, per una banda, i el foment i el reconeixement del monopoli de representació, per una altram no poden considerar-se likgades de forma mecànica, sí sembla clar que una estratègia governamental clarament no-corporativista hauria d'intentar disminuir al maxim el podet dels sindicats, a menys, òbviament, que es volgués aplicar una política econòmica "d'esquertes», la qual cosa, per molt que hom interpreti el concepte "esquerra» en sentit ampli, està molt liuny de la pràctica de l'actual Govern. 


\section{BIBLIOGRAFIA CITADA}

Banco de España (1983): «Informe anual 1982». Madrid, juny 1983.

S. Cartiilo (1975): «Franco desaparecido. Las tateas del movimiento obrero para que el franquismo desaparezca también.» «Nuestra Bandera», 82, novem. bre 1975 .

R. B. and D. Collier (1979): «Inducements versus constraints. Disaggregating corporatism», «American Political Science Review», 4, 1979.

C. Crouch (1979): The Politics of Industrial Relations, Fontana, Londres, 1979.

L. Fina i R. Hawkesworth (1981): Trade Unions and Collective Bargaining in Post-Franco Spain, 1981 (mecanografiat).

A. Gartido, E. Sanromà i J. Trullén (1983): «De fa moderación salarial a la recuperación de la inversión: Crítica a una cadena secuencial», "Revista Eco nómica», 68, Banca Catalana, setembre 1983.

INE (1980): La Renta Nacional en 1979 y su distribución, INE, Madrid, 1980.

G. Lehmbruch i P. C. Schmitter (eds.) (1982): Patterns of Corporatist PolicyMaking. Beverly Hills and London. Sage Publications 1982.

J. L. Malo de Molina (1983): «El mercado de trabajo y los salatios en España», "Investigaciones Económicas», 20, Madrid, gener-abril 1983.

J. Martínez Alier (1977): «El Pacto de la Moncloa. La lucha sindical y el nuevo corporativismo", «Cuadernos de Ruedo Ibérico», 58-60, París, 1977.

A. Meixide (1982): La estructura de los salarios en la industria española: un análisis del periodo de transición. Primer Congrés d'Economia i d'Econo. mistes d'Espanya. Barcelona, 8, 9, 10,11 desembre 1982.

C. Offe (1981): «The attribution of public status to interests groups: observations on the West German case» a S. Berger (ed.), Organizing Interests in Western Eutope. Cambridge: Cambridge University Press, 1981.

L. Panitch (1980): «Recent theorizations on corporatism. Reflections on a growth industry», «British Journal of Saciology», 2, 1980.

L. Panitch (1981): «Trade unions and the capitalist state», "New Left Review», gener-abril 1981.

V. Pérez Díaz (1984): «Políticas Económicas y pautas saciales de la transición: La doble cara del neocorporatismos, J. Linz (ed.): Problemas de España, tono I, La Sociedad, Planeta - Instituto de Estudios Económicos, Madrid, 1984. 
J. Roca (1984): «EIs pactes socials: cap a un nou corporativisme? El cas de l'Estat espanyol postfranquista (1977-1983) is. Tesi de Llicenciatura, Universitat Autònoma de Barcelona, març 1984.

J. A. Sagardoy Bergechea i D. León Blanco (1982): El poder sindical en Espa. ña, Planeta, Barcelona, 1982.

M. Salvati (1982): «Strutture politiche ed esiti economico», Stato e Mercato, 4, Bologna, 1982.

M. Salvati i G. Brosio (1979): «El auge de las políticas de mercado: Las relacio. nes industriales eutopeas en los años setenta.» «Sociología del Trabaịo», 3-4, 1980.

P. C. Schmitter (1974): «Still the century of corporatism?» a P. C. Schmitter and G. Lehmbruch (eds.), 1979.

P. C. Schmitter and G. Lehrmbruch (eds.) (1979): Trends Toward Corporatist Intermediation, Beverly Hills and London, Sage Publications, 1979.

R. Tamames (1981): «El Consejo Económico y Social, una obligación institucional», «El País», 29 novembre, 1 i 2 desembre 1981.

R. Tamames (1982): «Planificación en España: Una propuesta institucional», «Pensamiento Iberoamericano», 2, Madrid, juliol-desembre 1982.

Unión General de Trabajadores (1981): Acuerdo Nacional de Empleo. Textos, comentarios y disposiciones legales, Madrid, 1981. 